\title{
Article \\ Mosquitoes Larvicidal Activity of Ocimum kilimandscharicum Oil Formulation under Laboratory and Field-Simulated Conditions
}

\author{
John Bwire Ochola 1,2,*(D), Clifford Maina Mutero 1,3, Rose Muthoni Marubu ${ }^{1}$, Barbara Frei Haller 1,4, \\ Ahmed Hassanali ${ }^{2}$ and Wilber Lwande ${ }^{1}$
}

1 Bioprospecting Program, International Centre of Insect Physiology and Ecology, P.O. Box 30772, Nairobi 00100, Kenya; cmutero@icipe.org (C.M.M.); rmarubu@icipe.org (R.M.M.); bfreihaller@bluewin.ch (B.F.H.); wlwande@yahoo.com (W.L.)

2 Chemistry Department, School of Pure and Applied Sciences, Kenyatta University, P.O. Box 43844, Nairobi 00100, Kenya; ahmedhassanali786@gmail.com

3 Institute for Sustainable Malaria Control, School of Health Systems and Public Health, University of Pretoria, Private Bag X323, Pretoria 0001, South Africa

4 Institute of Pharmaceutical Sciences, ETH Zurich Vladimir-Prelog-Weg 1-5/10, 8093 Zurich, Switzerland

* Correspondence: jbwire@icipe.org; Tel.: +254-7-2296-1449

check for updates

Citation: Ochola, J.B.; Mutero, C.M.; Marubu, R.M.; Haller, B.F.; Hassanali, A.; Lwande, W. Mosquitoes Larvicidal Activity of Ocimum kilimandscharicum Oil Formulation under Laboratory and

Field-Simulated Conditions. Insects 2022, 13, 203. https://doi.org/ $10.3390 /$ insects 13020203

Academic Editor: Dionyssios Ch. Perdikis

Received: 9 November 2021 Accepted: 9 February 2022

Published: 16 February 2022

Publisher's Note: MDPI stays neutral with regard to jurisdictional claims in published maps and institutional affiliations.

Copyright: (C) 2022 by the authors. Licensee MDPI, Basel, Switzerland. This article is an open access article distributed under the terms and conditions of the Creative Commons Attribution (CC BY) license (https:// creativecommons.org/licenses/by/ $4.0 /)$.
Simple Summary: Mosquitoes are vectors of many severe diseases, notably malaria, yellow as well as dengue fever, and lymphatic filariasis. Vector control with synthetic chemical insecticides has been associated with resistance development and undesirable human and ecological effects. Ocimum kilimandscharicum oil formulation was evaluated for larvicidal activity against third instar mosquito larvae in the laboratory. The formulation was then compared with Bacillus thuringiensis subsp. israelensis (Bti) granules on An. gambiae larvae under field-simulated field trials. The $\mathrm{LC}_{50}$ for O. kilimandscharicum oil after $24 \mathrm{~h}$ against third instar larvae of An. gambiae was $0.74 \mathrm{ppm}$ while for the emulsified O. kilimandscharicum oil formulation against third instar larvae of An. gambiae and An. arabiensis was 0.07 and $0.31 \mathrm{ppm}$, respectively. The high bioactivity and sublethal toxic effects to offspring of treated mosquito larvae in terms of the disruption of larval morphological aspects suggest its high potential as a botanical larvicide for the control of disease vectors. The bioactive formulation had the advantage of high solubility in aqueous media; it is also easily produced, ecofriendly, and low-cost. Moreover, because O. kilimandscharicum can easily be widely cultivated and has high EO yields, it may provide a valuable alternative for the effective and eco-friendly control of disease vectors among developing and developed communities.

Abstract: Mosquitoes are vectors of many severe diseases, including malaria, yellow as well as dengue fever, and lymphatic filariasis. The use of synthetic chemical insecticides for mosquito control has been associated with resistance development and detrimental human, and ecological effects. For a safer alternative, the emulsified Ocimum kilimandscharicum oil formulation was evaluated for its larvicidal activity. The oil was analyzed by GC and GC/MS. The formulations were evaluated against third instar mosquito larvae in the laboratory and later compared with Bacillus thuringiensis subsp. israelensis against An. gambiae under field-simulated conditions. Thirty-nine compounds were identified in the oil, the main ones being D-camphor (36.6\%) and limonene (18.6\%). The formulation showed significant larval mortalities against An. gambiae and An. arabiensis larvae with $\mathrm{LC}_{50}$ of 0.07 and $0.31 \mathrm{ppm}$, respectively, at $24 \mathrm{~h}$. Under the field-simulated trial, within $24 \mathrm{~h}$, the formulation showed $98 \%$ mortality while Bti had achieved $54 \%$. On day three, it caused $100 \%$ mortality while Bti achieved $76.5 \%$. The high bioactivity and sublethal toxic effects to offspring of treated mosquito larvae, in terms of disruption of larval morphological aspects, suggest the high potential of the formulation as a botanical larvicide. The formulation, thus, may provide a valuable alternative for the effective and eco-friendly control of disease vectors.

Keywords: larvicide; malaria; mosquito control; botanical; formulation; biopesticide 


\section{Introduction}

Mosquitoes act as vectors of numerous harmful human diseases prevalent in over 100 tropical, subtropical, and other countries of the world [1,2]. These include malaria, yellow fever, dengue fever, chikungunya, filariasis, West Nile virus, and Japanese encephalitis, which all lead to massive morbidity and mortality and are a major economic burden within disease-endemic countries [3]. For many years, synthetic insecticides, including pyrethroids, organochlorine, organophosphate, and carbamate compounds, have been used as the main tools for mosquito control. However, these have had major disadvantages related to their harmful effects to the environment, humans, and other non-target organisms, as well as the loss of efficacy after repeated usage resulting from resistance to the insecticides [4-7]. As a result, vector-borne diseases appear to be re-emerging, as observed in the last two decades [8]. This has prompted the need for the identification of new ecofriendly and sustainable alternatives for their control. Such methods involve environmental management [9] and, more importantly, the use of botanicals that are eco-friendly, easily accessible at low cost, and safe for human health and the environment [10-13]. Unlike conventional insecticides, which are based on single active ingredients, plant-derived products constitute blends of compounds that act additively and synergistically on the behavior and/or physiological processes of insects. Moreover, natural phytochemical blends show resistance-mitigating effects over long periods [14].

Defense against insect vectors and mosquitoes is based on three essential modes of approach. Firstly, a reduction in the population density of adults by killing them. However, there have been shifting behaviors of target mosquitoes, such as changes in the locations of blood-feeding from indoor to outdoor [15]. The second strategy involves preventing insects from sucking blood from the host using repellents. Thirdly, and more importantly, concerns larval source management (LSM), which utilizes insecticides or larvicides to kill mosquito larvae $[16,17]$. Mosquito larvae, unlike adults, cannot shift from their habitat to avoid control activities, making LSM a more convenient strategy [17-19]. Thus, the focus on decreasing the mosquito population at the larval stage has the benefit of managing the vector before acquisition and spreading of the disease and disrupting its life cycle. Among the LSM strategic approaches, the usage of insect growth inhibitors, such as methoprene; organophosphate insecticides, such as temephos; and bacterial insecticides, such as $B t$ subsp. israelensis (Bti), is now extensively utilized [20-24]. However, these methods are not economically accessible to most rural communities and there have been special concerns on the longer-term use of synthetic chemicals in the environment and the potential of mosquito larvae to develop resistance to the chemical control tools [23].

In recent studies, great efforts have been directed to aromatic plants that produce essential oils (EOs) which contain substances with insecticidal effects. These studies explore the efficacy of certain aspects of botanical larvicides as well as their practical application against vectors in relation to public health [23-27]. Components contained in EOs not only display various mechanisms of action but also numerous levels of ability to infiltrate the insect cuticle and penetrate their bodies, which is precisely associated with the capability to deliver an insecticidal impact. The most efficient EOs evaluated as larvicides include Blumea densiflora, Auxemma glazioviana, Callitris glaucophylla, Cinnamomum microphyllum, Cinnamomum mollissimum, Cinnamomum rhyncophyllum, and Zanthoxylum oxyphyllum, which gave $\mathrm{LC}_{50}<10 \mathrm{ppm}$. Their chemical composition is mainly from the group of sesquiterpenes, aromatic acids, and ketones [26,28]. However, most of the previous studies on essential oils for use as larvicides failed to consider their low solubility in aqueous media. The low solubility results in very limited physiological effects on the larvae. Nevertheless, even at low doses in the aqueous media, oil droplets move up and coalesce and can form thin layers at the surface with reduced surface tension. This can make it extremely challenging for mosquito larvae to efficiently hang on the surface and inhale. As such, the detected adverse effects on the larvae can be caused largely by their failure to breathe on the surface during the period of exposure. This would, by extension, affect the nontarget aquatic organisms [8]. Moreover, the oil on the surface would also 
evaporate, thus rapidly limiting the duration of its negative effects on the larvae [27-31]. However, the low persistence of the effect of EOs and the formation of the film can be resolved through suitable formulation, such as using some encapsulation methods or oil in water nano-emulsions [31].

One of the most studied botanical sources is the Ocimum kilimandscharicum Gürke, whose extracts have shown considerable lethal activity against insect pests of agricultural and public health importance [32]. O. kilimandscharicum is a plant of the family Lamiaceae [33]. It is an important aromatic perennial evergreen shrub native to East Africa [34-36]. Its pharmacological potential or medicinal benefits have been well reported in the literature [35-37], but relatively few studies have been carried out on its larvicidal property against mosquitoes and formulation for its practical downstream application. The plant contains a rich reservoir of chemical constituents [38], some of which have known insecticidal properties. Therefore, this study outlines the results of the evaluation of the larvicidal potential of O. kilimandscharicum essential oil against An. gambiae, presents the use of a low-energy nano-emulsion delivery system with its volatile oil, and evaluates its larvicidal activity against two mosquito species under laboratory conditions. In addition, the performance of the water-based formulation against An. gambiae in field-simulated conditions was assessed. Furthermore, the effect of sublethal doses to post-larval stages in An.gambiae and An. arabiensis by the emulsified O. kilimandscharicum oil formulation was examined.

\section{Materials and Methods}

\subsection{Plant Collection}

The aerial parts of $O$. kilimandscharicum were collected from Isecheno Village, Kakamega County in western Kenya $\left(0^{\circ} 17^{\prime} \mathrm{N} ; 34^{\circ} 45^{\prime} \mathrm{E}\right)$. The environmental attributes, including location coordinates, were taken by a global positioning system (GPS) device, and a brief description of the plant sample was recorded in a notebook. The sample specimens were identified by a plant Taxonomist, Mr. Simon Mathenge (posthumous). The voucher specimens and $\mathrm{OK} / \mathrm{KAK} / 01 / 05$ and $\mathrm{OK} / \mathrm{KAK} / 02 / 10$ of the plants were deposited at the Herbarium of the National Museums of Kenya. The collected plant materials (leaves, flowers, or whole aerial part) were dried under shade at room temperature $\left(25 \pm 2{ }^{\circ} \mathrm{C}\right)$ for one week.

\subsection{Extraction of Essential Oil of O. kilimandscharicum}

Volatile essential oil from dried plant materials of $O$. kilimandscharicum was obtained by hydro-distillation with a Clevenger apparatus. Various quantities of each of the plant material were put into a ten-litre round-bottom flask, and water was added in the ratio of 1:3 (1 part of plant sample to 3 parts of water). The flask was then fitted with the Clevenger apparatus and a double pocket condenser. The plant materials were hydro-distilled for $4 \mathrm{~h}$. The extracted essential oil was collected on the water layer in the Clevenger apparatus. The procedure was repeated three times for each plant sample. The organic and aqueous layers were then left to separate in a separating funnel. The hexane extract was then dried with anhydrous sodium sulphate to remove traces of the water and then filtered. The solvent was then removed by distillation under reduced pressure. The yield of essential oil was determined, and the oil was stored in amber-colored vials at $4{ }^{\circ} \mathrm{C}$ until used.

\subsection{Identification of Constituents of O. kilimandscharicum Essential Oil}

The O. kilimandscharicum oils were analyzed using a gas chromatograph (GC) (HP7890A, Agilent Technologies, Wilmington, NC, USA) linked to a mass spectrometer (MS) operated in the electron impact mode (HP 5975 C, Agilent, Wilmington, NC, USA). The apparatus was equipped with a non-polar HP-5MS capillary column $(30 \mathrm{~m} \times 0.25 \mathrm{~mm}$ i.d.; $0.25-\mu \mathrm{m}$ film thickness, with $5 \%$ phenylmethyl silicone as the stationary phase; J \& W Scientific, Folsom, CA, USA). Helium $\left(1.2 \mathrm{~mL} \mathrm{~min}^{-1}\right)$ was used as the carrier gas. The oven temperature was programmed at $35^{\circ} \mathrm{C}$ (for $5 \mathrm{~min}$ ) to $280{ }^{\circ} \mathrm{C}$ at $10^{\circ} \mathrm{C} \mathrm{min}-1$, and 
then held isothermally at $280^{\circ} \mathrm{C}$ for $10.5 \mathrm{~min}$. An aliquot of $1 \mu \mathrm{L}$ of each oil $(100 \mathrm{mg}$ of each sample was dissolved in $10 \mathrm{~mL}$ of dichloromethane) was injected in the splitless mode (column effluent was split 1:1 for simultaneous detection). The ion source temperature was $230{ }^{\circ} \mathrm{C}$; electron ionization mass spectra were acquired at $70 \mathrm{eV}$ within a mass range of $38-550 \mathrm{Da}(\mathrm{Da})$ during a scan time of 0.73 scans s $^{-1}$. Compounds were identified using ChemStation software (Agilent) by comparison of mass spectral data of their retention time with library data: Adams and NIST 05. Identities of some constituents were confirmed by co-injection with commercially available authentic standards. Quantification was based on calibration curves (peak area vs. concentration) generated from authentic standards of identified compounds and by flame ionization gas chromatography (CG/FID), under the same conditions as in the GC/MS analysis.

\subsection{O. kilimandscharicum Essential Oil Formulations}

O. kilimandschericum essential oil formulations were prepared by mixing either with acetone or Tween 80 and water.

\subsubsection{Emulsified O. kilimandscharicum Oil Formulation}

This was prepared through a low-energy titration method [39] by mixing $8.33 \%(v / v)$ of Tween 80 (polyethylene glycol sorbitan monooleate, a non-ionic surfactant, and oil-in-water emulsifier) (Sigma-Aldrich, St. Louis, MO, USA), 16.67\% ( $v / v)$ of O. kilimandscharicum oil, and $75 \%(v / v)$ of water. To achieve a stable emulsion with a hydrophilic-lipophilic balance (HLB), values above 12 were targeted. This was achieved through the use of Tween 80 with an HLB of 15 . The essential oil and surfactant Tween- 80 were pooled together and homogenized by stirring for $30 \mathrm{~min}$ at $700 \mathrm{rpm}$ in a magnetic stirrer (Fisatom, Brazil). Then, water was added at a controlled flow rate of approximately $4 \mathrm{~mL} / \mathrm{min}$ and stirred for $1 \mathrm{~h}$. The final emulsion concentrate containing $16.67 \%$ of O. kilimandscharicum essential oil was made up to 1 litre with the addition of distilled water to obtain a $1000 \mathrm{ppm}$ stock solution that was diluted to various concentrations for use in the larvicidal bioassay. The $8.33 \%$ $(v / v)$ Tween 80 dissolved in water was used as the control.

\subsubsection{O. kilimanscharicum Essential Oil in a Solvent}

O. kilimanscharicum essential oil dissolved in an organic solvent (acetone) was prepared following the WHO method [40]. Stock solutions of the oils in acetone were prepared at a concentration of $50 \mathrm{mg} / \mathrm{mL}$, and then further serially diluted with acetone to six different concentrations. An appropriate amount of each of the stock solutions contained in shallow beakers was further diluted with distilled water to make $100 \mathrm{~mL}$ of the final test solutions with concentrations ranging from $0.1-1.0 \mathrm{ppm}$ and an acetone content not exceeding $1 \%$ $v / v$. A $1 \% v / v$ aqueous acetone solution served as a control.

\subsection{Sources of Mosquito Larvae}

The experiments were carried out with larvae of An. gambiae s.s and An. arabiensis mosquitoes all from colonies maintained at the International Centre of Insect Physiology and Ecology (ICIPE) Insect Mass Rearing and Containment Unit. Larvae for each species were reared separately under laboratory conditions where the water temperature was maintained at $28 \pm 2{ }^{\circ} \mathrm{C}$ throughout larval development. Hatched larvae were transferred to larger pans $(37 \mathrm{~cm} \times 31 \mathrm{~cm} \times 6 \mathrm{~cm})$ at densities of 200-300 larvae per pan at the 2nd instar and fed on Tetramin ${ }^{\circledR}$ fish food (Tetra GmbH, Melle, Germany). At the 3rd instar, they were ready to be used in the experiment. The rearing water was replaced with fresh water and diet after every two days. The pupae were held in plastic cups and transferred into standard $30 \mathrm{~cm} \times 30 \mathrm{~cm} \times 30 \mathrm{~cm}$ rearing cages where they hatched into adults.

\subsection{Larvicidal Activity of O. kilimandscharicum Oil}

O. kilimandscharicum oil dissolved in acetone and the emulsified O. kilimandscharicum oil formulation was evaluated for larvicidal activity against mosquito larvae. The tests 
were conducted in the laboratory following the standard WHO method, with some modification [40]. At first, mosquito larvae were subjected to a wide range of concentrations of the two formulated solutions and their respective controls to determine their activity profiles. Four aliquots from the stock solutions were prepared using the serial dilution method to give 4 concentrations $(1,0.5,0.25$, and $0.1 \mathrm{ppm})$, which gave $10 \%$ to $95 \%$ mortality in $24 \mathrm{~h}$ or $48 \mathrm{~h}$. The concentrations were subsequently applied to establish the lethal concentration of fifty percent $\left(\mathrm{LC}_{50}\right)$ and ninety percent lethal concentration $\left(\mathrm{LC}_{90}\right)$ values of the oil and aqueous formulation. Groups of $25(n=25)$ late third instar larvae were transferred through droppers to $200 \mathrm{~mL}$ beakers, containing $100 \mathrm{~mL}$ of the test blends with various doses. All the experiments were performed in triplicate with an equal number of controls that were set up simultaneously. Two controls were set up: one with acetone-Tween 80 in dechlorinated tap water and one positive control with Bti. (Under field-simulated evaluation). Each test was run three times on different days. Larval food Tetramin ${ }^{\circledR}$ in fish food (Tetra GmbH, Melle, Germany) was added to each test beaker using a dipstick (approximately $0.02 \mathrm{~g}$ ) to enable long-term observations. The food was supplemented every $48 \mathrm{~h}$ and test blends were topped up with water up to $100 \mathrm{~mL}$ to ensure the test sample did not change. The test beakers were maintained at $25-28^{\circ} \mathrm{C}$ and a photoperiod of $12 \mathrm{~h}$ light followed by $12 \mathrm{~h}$ darkness (1:12D). Larval mortality was scored after $24 \mathrm{~h}$ and $48 \mathrm{~h}$ of exposures. Larvae were considered dead if they remained irresponsive within two minutes when gently probed with a pipette. If more than $10 \%$ of the control larvae developed into pupae during the experiment, the experiment was abandoned and repeated because late instar larvae do not ingest $24 \mathrm{~h}$ before pupation, and too many larvae might have endured merely because they were too old. For cases where mortality was between 5 and 20\%, the moralities of treated units were corrected using Abbott's formula [41] as indicated in Equation (1).

$$
\operatorname{Mortality}(\%)=\frac{[X-Y]}{X} 100
$$

where $X$ is the percentage survival in the untreated control and $Y$ is the percentage survival in the treated group.

\subsection{Effects of Sublethal Doses of Emulsified O. kilimandscharicam Oil Formulation}

To determine the effects of sublethal exposure to emulsified O. kilimandscharicum oil formulation during larval development, beakers with third instar larvae were obtained from the insectary and were exposed to the above experimental conditions for $48 \mathrm{~h}$. These experiments were replicated 4 times. For each experiment, four controls were used containing the sterilized water and four treatments for each of the three sublethal emulsified O. kilimandscharicum oil formulations concentrations $\left(\mathrm{LC}_{20}, \mathrm{LC}_{50}\right.$, and $\left.\mathrm{LC}_{70}\right)$. During the 48-h exposure period, each beaker was provided with $20 \mathrm{mg}$ of Tetramin ${ }^{\circledR}$ in fish food (tetramine) per day. All dead and moribund larvae were counted after 24 and $48 \mathrm{~h}$. After the 48-h exposure period for each replicate, all surviving larvae from the same treatment were pooled and placed in new breakers with fresh salt-treated water only. All emerging pupae were placed in plastic cups $(100 \times 50 \mathrm{~mm}$ diameter $)$, which were placed in $30 \times 30 \times 30 \mathrm{~cm}$ cages, separated by treatment and replicate. The emerging adults were fed $6 \%$ sugar solution ad libitum. Under the microscope, morphological defects were monitored at intervals of $24 \mathrm{~h}$ until the death of the last larva or emergence of an adult.

\subsection{Larvicidal Activity under Field-Simulated Conditions}

Larvicidal activity of the emulsified $O$. kilimandscharicum oil formulation was evaluated under field-simulated conditions using natural mosquito breeding sites in Jaribuni village $\left(03^{\circ} 37.3^{\prime}\right.$ S; $039^{\circ} 44.6^{\prime}$ E), Kilifi county in Kenya, in September and in October during the short rain season. The WHO mosquito larvicidal protocol was applied under the fieldsimulated trial method [40]. Multiple artificial 5 L clay pots were used in the field. The experiment was carried out using $3 \mathrm{rd}$ instar An. gambiae larvae which were reared in the laboratory. The pots were filled with $1 \mathrm{~kg}$ of sterilized soil and $3 \mathrm{~L}$ of water from the 
mosquito breeding habitat. The set setup was left for $\sim 24 \mathrm{~h}$ and then batches of $50 \mathrm{An}$. gambiae s.s. larvae were introduced in each pot. After 2 to $3 \mathrm{~h}$ of larval acclimatization, the containers were treated with $0.1,0.5$, and 1 ppm of emulsified 0 . kilimandscharicum oil formulation concentrations based on the volume of water in the pot using perforated jars. Bti granules, VectoBac WDG/WG-3000 ITU, were used as positive control with a concentration of $28 \mathrm{ppm}$, i.e., the concentration of 4 Bti granules per $10 \mathrm{~cm} \times 10 \mathrm{~cm}$ surface area, as recommended in the WHO Larval Source Management protocol [42]. The Bti granules were broadcasted in a randomized manner over the water surfaces. The pots were covered with nylon mesh screens to prevent other mosquitoes or other insects from laying eggs, and to protect the water from falling debris. The water level in each pot was maintained by topping up as necessary. Five replicates of each dosage of the essential oil formulation were used. Bti granules were used as the positive control. The larvae in the pots were assessed after $24 \mathrm{~h}$ and $48 \mathrm{~h}$, whereby live ones were counted and recorded. For low-dosage sample materials, the persistence of the larvae, pupae, and pupal skins was assessed for 7 days. Beyond this time, all larvae had pupated and developed into adults. $\mathrm{pH}$ and water temperature values were noted during the evaluation period.

\subsection{Data Analysis}

The mortality rate was expressed as $\%$ mean \pm S.D of experimental replicates for each dosage of the test solutions after correction using Abbotts's formulae based on the data obtained from the negative control. Log probit analysis [41] was used to determine the $\mathrm{LC}_{50}$ and $\mathrm{LC}_{90}$ at their associated $95 \%$ fiducial limits at upper and lower confidence limit (UCL/LCL) using R software version 3.2.3 [43]. A comparison of $\mathrm{LC}_{50}$ and $\mathrm{LC}_{90}$ values was based on confidential limits for each population, whereby there was no significant difference if two confidence intervals overlapped. The data obtained were analyzed using descriptive statistical analyses. Means were compared by measured ANOVA followed by the post-hoc Tukey HSD test and $p$ values of less than 0.05 were considered statistically significant. Graphs were designed using Graph Pad Prism version 7.01 for Windows (GraphPad) Software, San Diego, CA, USA).

\section{Results}

\subsection{Oil Yield of O. kilimandscharicum}

The average percentage yield of the essential oil from dried aerial parts of $O$. kilimandscharicum was $3.51 \pm 0.56 \%$ during the wet season and $3.68 \pm 0.33 \%$ during the dry season. The two seasons that prevail in Kenya are the dry season (December-March and July-October) and wet season (April-June and November), which both impact the oil yield. Through the seasons, the oil yield obtained in the wet season was greater than that harvested in the dry season, although not significantly different. The oil had a relative density of 0.98 , which is lower than that of water. The oil color was light yellow.

\subsection{Chemical Composition of the Essential Oil}

Thirty-nine major compounds identified in O. kilimandscharicum oil. D-camphor was the most abundant constituent $(36.6 \%)$, followed by limonene $(18.6 \%)$, camphene $(7.1 \%)$, linalool $(4.3 \%)$, terpinen-4-ol (3.9\%), $\alpha$-terpineol $(3.6 \%)$, terpinolene $(2.2 \%)$, and sesquisabinene $(2.1 \%)$ (Table 1$)$. 
Table 1. Chemical composition of the essential oil of O. kilimandscharicum harvested in the dry season.

\begin{tabular}{|c|c|c|}
\hline RI & Compounds & Relative Content (\%) \\
\hline 923 & Tricyclene & 0.71 \\
\hline 931 & $\alpha$-Pinene & 1.94 \\
\hline 946 & Camphene & 7.14 \\
\hline 989 & Myrcene & 1.88 \\
\hline 1003 & $\alpha$-Phellandrene & 0.76 \\
\hline 1008 & $\delta$-2-Carene & 0.68 \\
\hline 1024 & $p$-Cymene & 0.23 \\
\hline 1029 & Limonene & 18.61 \\
\hline 1046 & (E)- $\beta$-Ocimene & 0.92 \\
\hline 1059 & $\gamma$-Terpinene & 1.05 \\
\hline 1085 & $\alpha$-Terpinolene & 2.23 \\
\hline 1093 & 6-Camphenol & 0.6 \\
\hline 1098 & Trans-sabinene hydrate & 0.86 \\
\hline 1100 & Linalool & 4.32 \\
\hline 1143 & Camphor & 36.58 \\
\hline 1158 & Isoborneol & 0.14 \\
\hline 1165 & Borneol & 0.97 \\
\hline 1167 & $\alpha$-Terpineol & 3.6 \\
\hline 1180 & Terpinen-4-ol & 3.9 \\
\hline 1247 & Geranial & 0.21 \\
\hline 1286 & (E)-Linalool oxide acetate & 1.4 \\
\hline 1351 & $\alpha$-Cubebene & 0.08 \\
\hline 1357 & Eugenol & 0.14 \\
\hline 1378 & $\alpha$-Copaene & 0.5 \\
\hline 1419 & (E)- $\beta$-Caryophyllene & 1.94 \\
\hline 1433 & $\beta$-Copaene & 1.07 \\
\hline 1450 & trans-Muurola-3,5-diene & 0.26 \\
\hline 1455 & $\alpha$-Humulene & 0.38 \\
\hline 1470 & Bicyclogermacrene & 0.47 \\
\hline 1476 & Geranyl propanoate & 1.28 \\
\hline 1480 & $\gamma$-Muurolene & 0.12 \\
\hline 1482 & Germacrene D & 1.17 \\
\hline 1497 & Viridiflorene & 0.46 \\
\hline 1503 & $\alpha$-Bisabolene & 0.12 \\
\hline 1541 & Sesquisabinene hydrate, cis- & 2.12 \\
\hline 1601 & Humulene epoxide II & 0.08 \\
\hline 1700 & Geranyl propanoate & 0.17 \\
\hline 1470 & Dauca-5,8-diene & 0.23 \\
\hline
\end{tabular}

Retention indices (RIs) were experimentally determined against $C_{5}-C_{18}$ n-alkanes using the non-polar HP-5MS capillary column $(30 \mathrm{~m} \times 0.25 \mathrm{~mm}$ i.d.; $0.25 \mu \mathrm{m}$ film thickness, with 5\% phenylmethyl silicone as the stationary phase; J \& W Scientific, Folsom, CA, USA). 
The content was expressed as percentages obtained by integrating the gas chromatography peak area in the O. kilimandscharicum essential oil. RI: retention index. Conditions of analysis involved gas chromatography associated with mass spectrometer (GC-MS) THERMO DSQ II. Chemical constituents were identified by comparison of the mass spectra obtained with published spectra [44].

\subsection{Laboratory Larvicidal Bioassay}

The concentration of $O$. kilimandscharicum oil dissolved in acetone which induced the median larvicidal activity $\left(\mathrm{LC}_{50}\right)$ after $24 \mathrm{~h}$ and $48 \mathrm{~h}$ against third instar larvae of $A n$. gambiae was 0.74 and $0.31 \mathrm{ppm}$, respectively (Table 2). On the other hand, the median larvicidal potency $\left(\mathrm{LC}_{50}\right)$ of the emulsified O. kilimandscharicum oil formulation after $24 \mathrm{~h}$ against third instar larvae of An. gambiae and An. arabiensis was 0.74 and $3.45 \mathrm{ppm}$, and the $\mathrm{LC}_{90}$ was 2.39 and $4.72 \mathrm{ppm}$, respectively (Table 2). After $48 \mathrm{~h}$, the $\mathrm{LC}_{50}$ was $0.14 \mathrm{ppm}$ for both against the third instar larvae of An. gambiae and An. arabiensis, while the LC 90 was 0.22 and 1.63 ppm, respectively (Table 2 ).

Table 2. Mortality level (\%) of 3rd instar mosquito larvae.

\begin{tabular}{|c|c|c|c|c|c|c|c|c|c|c|c|}
\hline \multirow[b]{2}{*}{ Treatment } & \multirow{2}{*}{$\begin{array}{l}\text { Mosquito } \\
\text { Species }\end{array}$} & \multirow{2}{*}{$\begin{array}{c}\text { Time } \\
\text { (h) }\end{array}$} & \multicolumn{5}{|c|}{ Concentrations (ppm)/\% Mortality } & \multicolumn{2}{|c|}{ Lethal Concentration } & \multicolumn{2}{|c|}{ Treatment Response } \\
\hline & & & $\begin{array}{c}\text { Control } \\
\text { (-ve)-Water }\end{array}$ & 0.1 & 0.25 & 0.5 & 1 & $\mathrm{LC}_{50}(95 \% \mathrm{CL})$ & $\mathrm{LC}_{90}(95 \% \mathrm{CL})$ & $\mathbf{R}^{2}$ & $\mathrm{X}^{2}, \mathrm{df}, p$-Value \\
\hline \multirow{2}{*}{$\begin{array}{l}\text { O. kilimandscharicum } \\
\text { oil in acetone }\end{array}$} & \multirow{2}{*}{ An. gambiae } & 24 & 0.0 & 4.7 & 18.2 & 37.1 & 60.0 & $\begin{array}{c}0.74 \\
(0.07-0.97) \\
\end{array}$ & $\begin{array}{c}3.45 \\
(2.13-8.73) \\
\end{array}$ & 0.9929 & $\begin{array}{c}\mathrm{X}^{2}=1954.00 \\
\mathrm{df}=18 p<0.0001\end{array}$ \\
\hline & & 48 & 0.0 & 20.4 & 43.6 & 63.4 & 100.0 & $\begin{array}{c}0.31 \\
(0.11-0.87)\end{array}$ & $\begin{array}{c}1.82 \\
(0.06-51.63)\end{array}$ & 0.9786 & $\begin{array}{c}\mathrm{X}^{2}=2025.06 \\
\mathrm{df}=4, p<0.0001\end{array}$ \\
\hline \multirow{4}{*}{$\begin{array}{l}\text { O. kilimandscharicum } \\
\text { water-emulsion }\end{array}$} & \multirow{2}{*}{ An. gambiae } & 24 & 0.0 & 34.2 & 67.2 & 75.9 & 99.4 & $\begin{array}{c}0.07 \\
(0.61-0.13)\end{array}$ & $\begin{array}{c}2.39 \\
(1.08-19.70)\end{array}$ & 0.794 & $\begin{array}{c}\mathrm{X}^{2}=1923.69 \\
\mathrm{~d} 8, p<0.0001\end{array}$ \\
\hline & & 48 & 0.0 & 21.0 & 94.0 & 99.9 & 100.0 & $\begin{array}{c}0.14 \\
(0.09-0.20)\end{array}$ & $\begin{array}{c}0.22 \\
(0.10-0.49)\end{array}$ & 0.9394 & $\begin{array}{c}\mathrm{X}^{2}=794.00 \\
\mathrm{Df}=4, p<0.0001\end{array}$ \\
\hline & \multirow{2}{*}{$\begin{array}{l}\text { An. } \\
\text { arabiensis }\end{array}$} & 24 & 0.0 & 29.9 & 46.2 & 59.0 & 71.0 & $\begin{array}{c}0.31 \\
(0.18-0.50) \\
\end{array}$ & $\begin{array}{c}4.72 \\
(1.74-117.50)\end{array}$ & 0.87635 & $\begin{array}{c}\mathrm{X}^{2}=4688.80 \\
\mathrm{df}=18, p<0.0001\end{array}$ \\
\hline & & 48 & 0.0 & 43.2 & 62.1 & 74.8 & 84.8 & $\begin{array}{c}0.14 \\
(0.07-0.20)\end{array}$ & $\begin{array}{c}1.63 \\
(0.86-7.52)\end{array}$ & 0.8394 & $\begin{array}{c}\mathrm{X}^{2}=3052.08 \\
\mathrm{~d} 8, p<0.0001\end{array}$ \\
\hline \multirow{4}{*}{$\begin{array}{l}\text { Emulsion/surfactant } \\
\text { (Tween 80) }\end{array}$} & \multirow{2}{*}{$\begin{array}{l}\text { An. } \\
\text { arabiensis }\end{array}$} & 24 & 0.0 & 0.4 & 1.1 & 2.3 & 4.3 & $\begin{array}{c}75.28 \\
(10.70)\end{array}$ & $\begin{array}{l}1877.55 \\
(69.99)\end{array}$ & 0.9978 & $\begin{array}{c}\mathrm{X}^{2}=47.97 \\
\mathrm{df}=18, p<0.0001\end{array}$ \\
\hline & & 48 & 0.0 & 0.9 & 2.3 & 4.3 & 7.7 & $\begin{array}{c}30.162 \\
(8.63-1145.80)\end{array}$ & $\begin{array}{c}648.88 \\
(68.05- \\
475,024.38)\end{array}$ & 0.9973 & $\begin{array}{c}\mathrm{X}^{2}=75.11 \\
\mathrm{df}=18, p<0.0001\end{array}$ \\
\hline & \multirow{2}{*}{ An. gambiae } & 24 & 0.0 & 1.3 & 2.6 & 4.1 & 6.3 & $\begin{array}{c}172.57 \\
(14.78-0.00)\end{array}$ & $\begin{array}{c}12,795.98 \\
(172.20\end{array}$ & 0.9694 & $\begin{array}{c}\mathrm{X}^{2}=111.91 \\
\mathrm{df}=18, p<0.0001\end{array}$ \\
\hline & & 48 & 0.0 & 1.6 & 3.6 & 6.1 & 9.9 & $\begin{array}{c}31.99 \\
(8.13-615.21)\end{array}$ & $\begin{array}{c}1011.90 \\
(78.57- \\
3,997,163.24)\end{array}$ & 0.9847 & $\begin{array}{c}\mathrm{X}^{2}=142.31 \\
\mathrm{df}=18, p<0.0001\end{array}$ \\
\hline
\end{tabular}

$\mathrm{LC}_{50}=$ Mean lethal concentration, $95 \% \mathrm{CL}=$ upper/lower confidence Interval. Comparison of $\mathrm{LC}_{50}$ and $\mathrm{LC}_{90}$ values based on confidential limits in case C.L. Overlap showed no significant differences at $p<0.05$. The emulsified $O$. kilimandscharicum oil formulation showed comparable levels of activity against third instar larvae of An. gambiae and An. arabiensis, as shown in Table 3. Compared to negative controls, the $\mathrm{LC}_{50}$ for emulsified O. kilimandscharicum oil formulation was the lowest and substantially reduced survival rates of An. gambiae and An. arabiensis. The $\mathrm{LC}_{50}$ for the formulation was highest against $A n$. gambiae larvae. There was considerable vulnerability variation amongst the two mosquito species to the formulation based on the degree of overlap of fiducial limits (FL/CL, $\alpha=0.05, p=0.05)$.

From the results, emulsified O. kilimandscharicum oil formulation significantly exhibited higher larvicidal activity in comparison to the oil dissolved in acetone. On the other hand, the difference in larvicidal activity of the emulsified O. kilimandscharicum oil formulation was significantly different from the nonionic surfactant and emulsifier Tween 80 . The $\mathrm{LC}_{50}$ of emulsified $O$. kilimandscharicum oil formulation was $0.07 \mathrm{ppm}$ while the aqueous non-ionic surfactant was at $172.57 \mathrm{ppm}$ after $24 \mathrm{~h}$ exposure against An. gambiae larvae. This was a quite very low activity for Tween 80 which gave high $\mathrm{LC}_{50}$ values. As such, Tween 80 did not have any significant effect on larvae mortality $(p>0.05)$. Furthermore, 100\% 
larval persistence was observed in the untreated (water only) control group for the whole experiment cycle.

Table 3. Effect of larval exposure to sublethal doses of emulsified O. kilimandscharicum oil formulation.

\begin{tabular}{ccccc}
\hline \multirow{2}{*}{$\begin{array}{c}\text { Treatment } \\
(\mathbf{p p m})\end{array}$} & \multicolumn{2}{c}{ An. gambiae } & \multicolumn{2}{c}{ An. arabiensis } \\
\cline { 2 - 5 } & $\begin{array}{c}\text { Mean No of } \\
\text { Pupae (M } \pm \text { SE) }\end{array}$ & $\begin{array}{c}\text { Mean No of } \\
\text { Adults }(\mathbf{M} \pm \mathbf{S E})\end{array}$ & $\begin{array}{c}\text { Mean No of } \\
\text { Pupae (M } \pm \mathbf{S E})\end{array}$ & $\begin{array}{c}\text { Mean No of } \\
\text { Adults (M } \pm \mathbf{S E})\end{array}$ \\
\hline $\mathrm{LC}_{70}$ & $31.3 \pm 1.68 \mathrm{a}$ & $29.0 \pm 2.3 \mathrm{a}$ & $32.0 \pm 1.15 \mathrm{a}$ & $22.3 \pm 1.28 \mathrm{a}$ \\
\hline $\mathrm{LC}_{50}$ & $49.7 \pm 1.68 \mathrm{~b}$ & $44.7 \pm 2.3 \mathrm{~b}$ & $45.0 \pm 1.15 \mathrm{~b}$ & $39.0 \pm 1.28 \mathrm{~b}$ \\
\hline $\mathrm{LC}_{20}$ & $71.3 \pm 1.68 \mathrm{c}$ & $67.0 \pm 2.3 \mathrm{c}$ & $65.0 \pm 1.15 \mathrm{c}$ & $62.3 \pm 1.28 \mathrm{c}$ \\
\hline Control & $79.0 \pm 1.68 \mathrm{~d}$ & $75.3 \pm 2.3 \mathrm{~d}$ & $73.0 \pm 1.15 \mathrm{~d}$ & $68.0 \pm 1.28 \mathrm{c}$
\end{tabular}

Number (mean \pm SE) of pupae and adults emerged from 100 larvae exposed to sublethal doses of emulsified $O$. kilimandscharicum oil formulation. Means followed by the same letter are not significantly different in a Tukey test, at $p<0.05$.

\subsection{Effects of Sublethal Doses of the Emulsified O. kilimandscharicum Oil Formulation}

It was observed that sublethal doses of emulsified O. kilimandscharicum oil formulation caused low mortality (Table 3).

The number of mosquitoes larvae that developed to the adult stage decreased with increasing concentrations of emulsified O. kilimandscharicum oil formulation (Table 3). Most of the larvae in the treatment experiment revealed growth disruption larvae, as demonstrated in Figure 1. Figure 1a,e display a normal An. gambiae s.s and An. arabiensis larval-pupal intermediary, respectively, noted in the negative control. The abnormally increased development rate of An. gambiae larvae led to insufficient myelinization, as revealed in Figure 1b, whereas during the same time, stunted An. arabiensis larval-pupal intermediate was observed in Figure 1c,f,g which were subjected to a lower dose of the formulation, showing uncharacteristic abnormal and dead larval-pupal intermediate of An. gambiae and An. arabiensis, respectively. Despite molting being sustained, the growth of the infantile phases was extensively impacted. The microscopic examination of the dead immature phases at $30 \times$ enlargement showed morphologic deficiencies. This was manifested similar to abnormal dead larval pupal intermediates in An. gambiae, as well as crumbled mouthparts and wings within the pupal exuvial, as shown in Figure 1d. The adults that emerged from the lower dose application were incapable of breaking from the pupal caste and perished on the surface of the test solution for the case of An. arabiensis, as shown in Figure 1h. Generally, the formulation at lower doses caused a prolonged larval phase period of four days before pupation, unlike the negative control.

\subsection{Field-Simulated Evaluation}

The results of the field-simulated evaluation are illustrated in Figure 2. The emulsified O. kilimandscharicum oil formulation had great efficacy compared with Bti granules used as a positive control. After 1 day of treatment, the formulation at $0.5 \mathrm{ppm}$ led to $98 \%$ larval mortality, whereas Bti at 28 ppm exhibited larval mortality of $54 \%$. When the emulsified $O$. kilimandscharicum oil formulation attained $100 \%$ mortality on day 3, Bti was at $76.5 \%$, as indicated in Figure 2. The survival of larvae in the control remained high since there was low mortality and only started to decline when pupation commenced. 


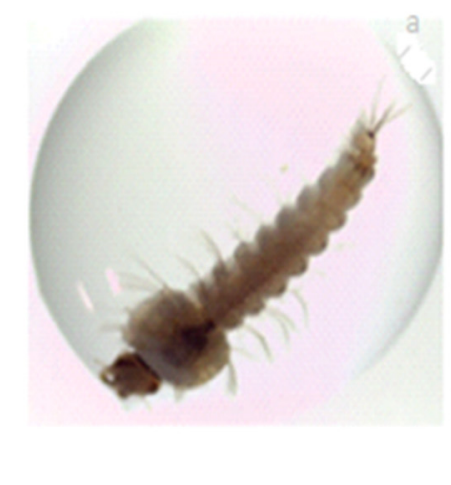

(a)

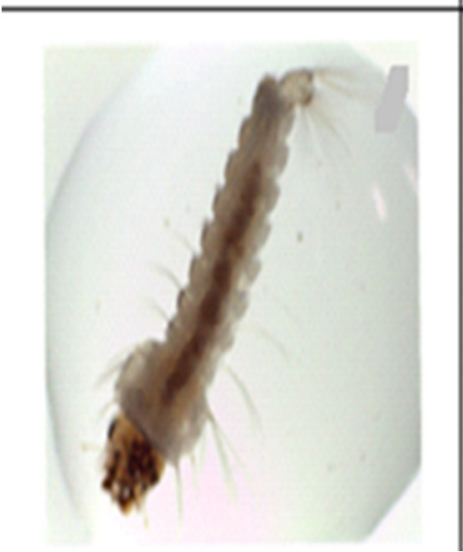

(e)

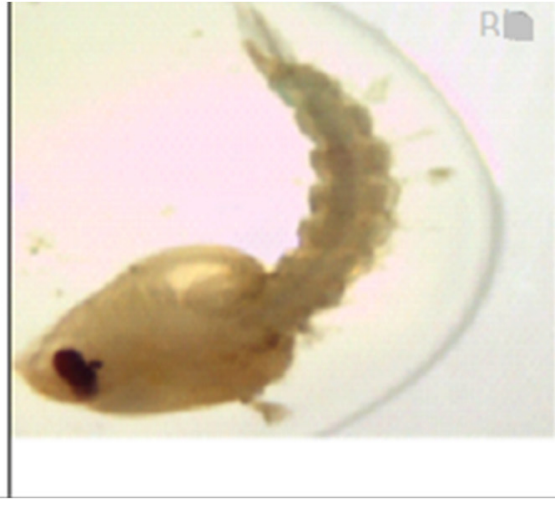

(b)

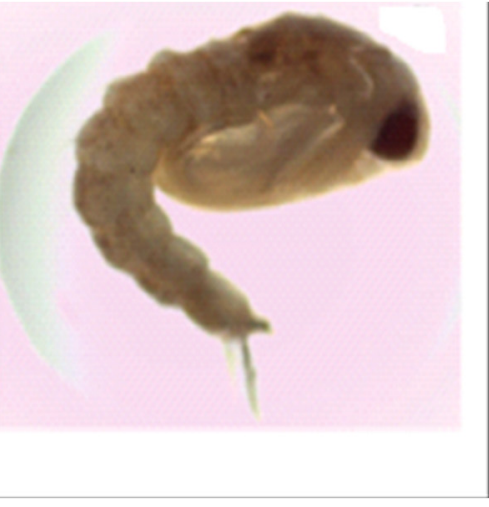

(c)

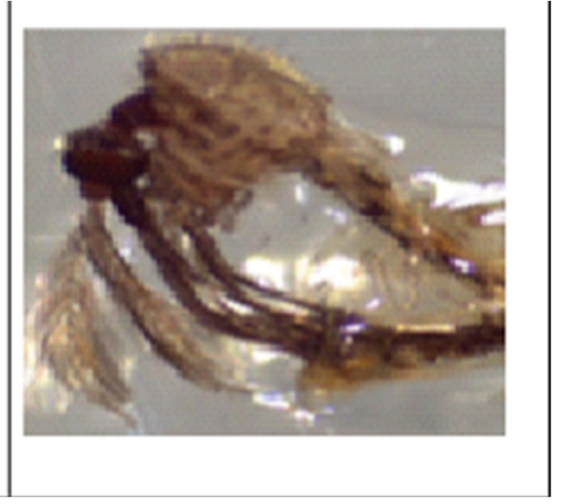

(d)

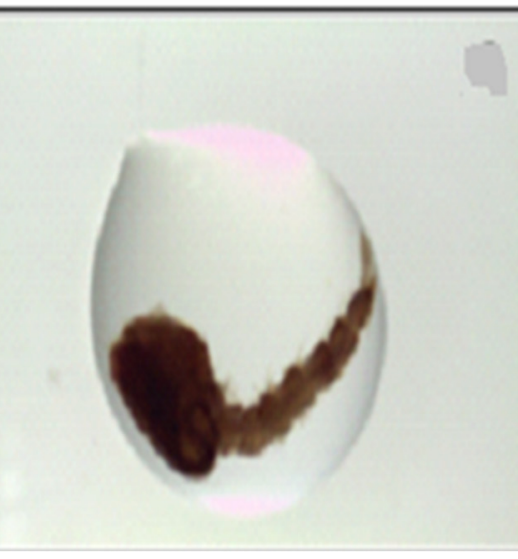

(f)

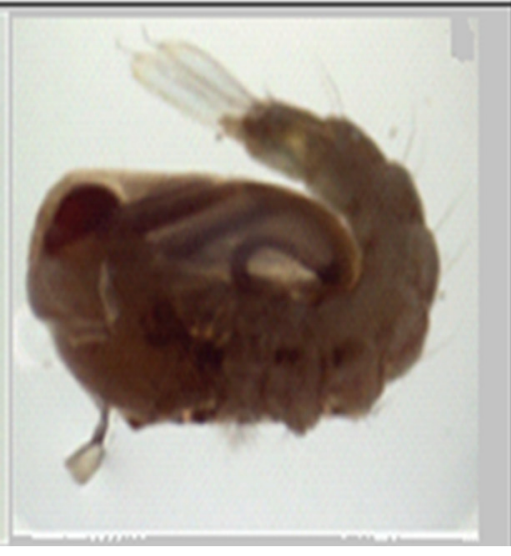

$(\mathrm{g})$

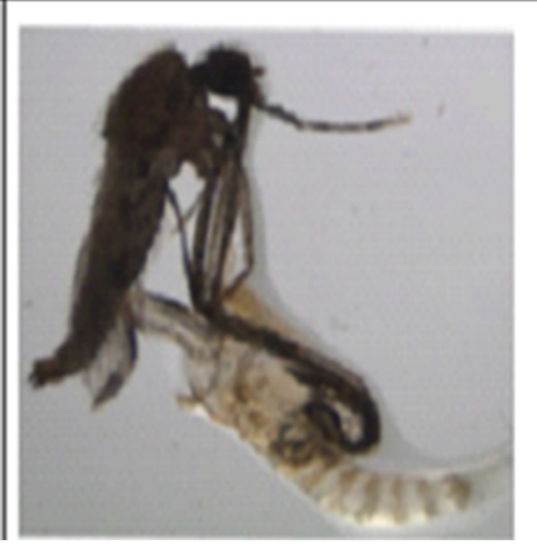

(h)

1. Effect of sub-lethal dose of emulsified O. kilimandscharicum oil formulation on mosquito larval development, pupation, and adult stage. (a) Normal An gambiae s.s. (b) Demelanized An. gambiae s.s larval-pupal intermediate. (c) Abnormal An. gambiae s.s larval-pupal intermediate. (d) Arrested adult emergence in An.gambiae. (e) Abnormal An. arabiensis larvae in negative control solution. (f) A stunted An. arabiensis larval-pupal intermediate. (g) Abnormal An. arabiensis larval-pupal intermediate. (h) Failed adult emergence in An. Arabiensis. 


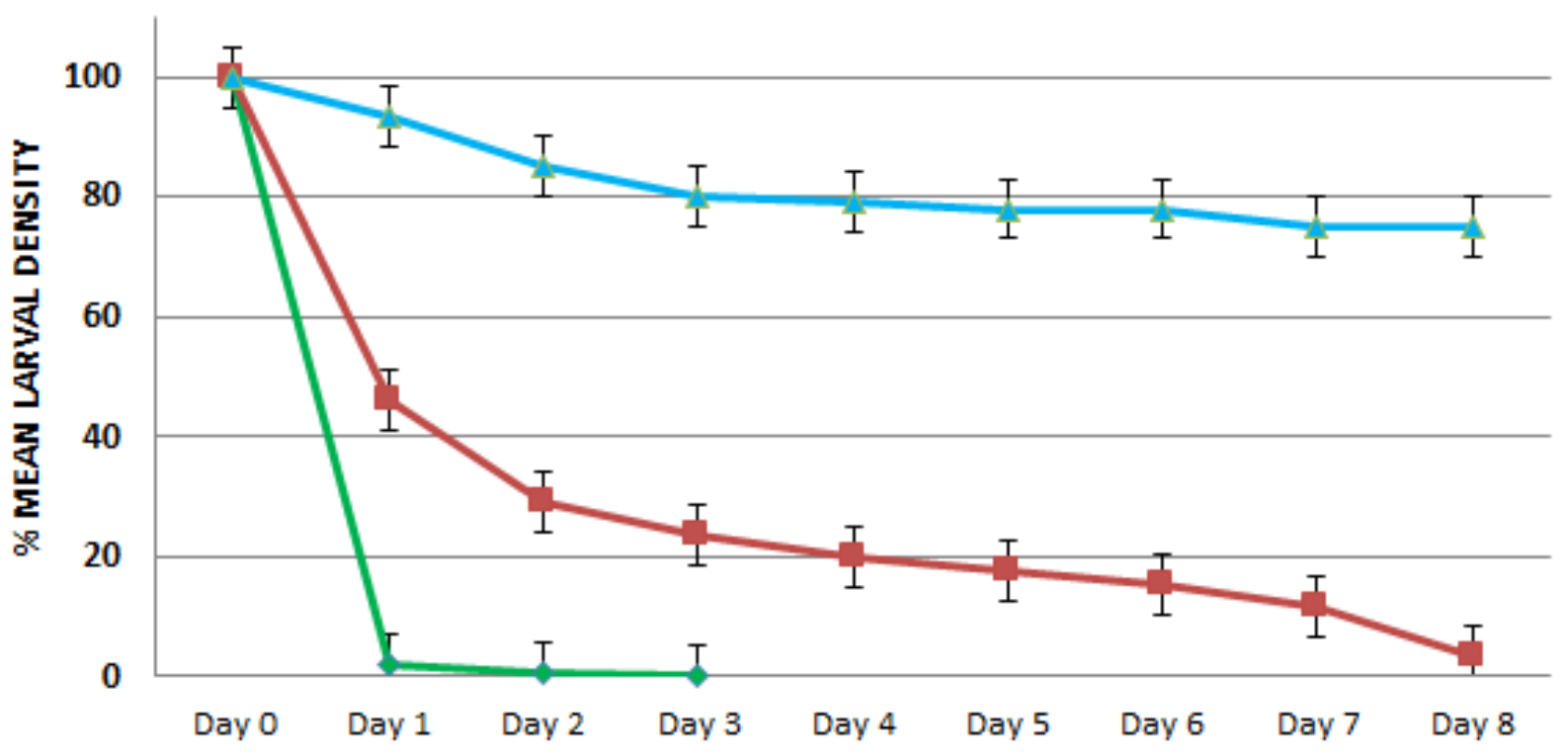

O.kilimandscharicum water miscible fomulation

\section{$(0.5 \mathrm{ppm})=$ Bti granules $(28 \mathrm{ppm})$}

$\rightarrow-$ Untreated control

Figure 2. Larvicidal activity under field-simulated conditions in Kilifi of emulsified O. kilimandscharicum oil formulation and Bti granules.

\section{Discussion}

Even though there has been a recent decline in the global prevalence of some vector diseases, such as malaria, the vector diseases remain to be responsible for high morbidity and mortality in sub-Sahara Africa [45]. There is the necessity to seek alternative ways to combat the menace particularly in the Africa continent [46]. In this study, we explored the use of $O$. kilimandscharicum essential oil as a source of an effective mosquito larvicide.

There was a difference in the oil yield of $O$. kilimandscharicum which could be attributed to the two weather seasons when the samples were collected. The two-weather condition that prevails in Kenya concerns the dry season (December-March and July-October) and the wet season (April-June and November). Through the seasons, the oil yield obtained in the wet season was greater than that harvested in the dry season, although not significantly different. The major chemical composition of $O$. kilimandscharicum concerns camphor, 1,8-cineole, linalool, and limonene, as reported in previous studies [33,47].

The $\mathrm{LC}_{50}$ for the unformulated oil and that of the emulsified O. kilimandscharicum oil was $\mathrm{LC}_{50}=0.74$ and $\mathrm{LC}_{50}=0.07 \mathrm{ppm}$, respectively. Our results suggest that the $O$. kilimandscharicum essential oil bioactivity was enhanced to a more effective larvicide when formulated. The $\mathrm{LC}_{50}$ for the emulsified O. kilimandscharicum oil formulation was $0.14 \mathrm{ppm}$ against $A n$. arabiensis. The comparable improved performance was obtained with neem oil after formulation [46], whereby the improved lethal concentration $\left(\mathrm{LC}_{50}\right)$ of the neem water emulsion formulation against An. stephensi, Cx. quinquefasciatus and Ae. aegypti was reported to as 1.6, 1.8, and $1.7 \mathrm{ppm}$, respectively [48]. Moreover, our findings indicate that higher doses were toxic to the larvae while sublethal doses of the formulation reduced their life spans. Similar results have been reported for Culex quinquefasciatus when exposed to sublethal doses of cypermethrin for both larvae and adults [49]. The toxic effect was attributed to physiological damage caused to the nervous system and associated aberrations due to abnormal hormone release and dehydration because of exposure to cypermethrin. In this study, it was observed that, at sublethal doses, the emulsified O. kilimandscharicum oil formulation induced developmental disruptions, as indicated in Figure 1. The bioactivity was attributed to interruption of the endocrine system stability by essential oils and their 
constituents which disturb their biochemical processes. The instability may result from neurotoxicity and capacity to act as insect growth regulators, disrupting the ordinary process of morphogenesis [50,51]. The bioactivity may be associated with the presence of monoterpenoids and sesquiterpenes, including camphor, D-limonene, myrcene, terpineol, linalool, and pulegone, as reported in Table 1, which acted in synergy. The compounds have also been previously assessed for their neurotoxicity against house flies and German cockroaches [52]. Camphor, the major constituent of the essential oil of O. kilimandscharicum, has similarly shown strong insecticidal bioactivity against postharvest insect pests [53]. Neurotoxicity by essential oils in insects is characterized by hyperactivity leading to rapid "knock-down" and immobilization of the organism [54]. Furthermore, several studies have established that essential oils from aromatic plants inhibit acetylcholinesterase (AChE) in different insect species [55-57]. AChE plays a role in cholinergic synapses that are essential for insects and higher animals [58]. Inhibition of AChE leads to a high deposit of acetylcholine at the synapses. This puts the post-synaptic membrane in a state of perpetual stimulation, leading to ataxia, the wide-ranging deficiency of conformity in the neuromuscular system, and even death $[59,60]$. On the other hand, the observed stunted growth and growth disruption among the larvae under a low dose of the formulation of O. kilimandscharicum oil could be attributed to averting feeding through chemoreception, possibly due to volatile organic constituents and the disruption of endocrine functions, causing regulated insect growth and, thus, triggering developmental irregularities [61] The larvae stage is critical to the life of an insect and is susceptible to specific toxic effects on specific enzyme systems as well as disturbances in hormonal triggering [62]. Furthermore, larvae exposure to sublethal doses of emulsified $O$. kilimandscharicum oil formulation could lead to a reduction in vectorial capacity for disease vector populations, following the reduced lifespan of subsequent adults [63].

Under the simulated-field trial, the emulsified O. kilimandscharicum oil formulation exhibited significant larvicidal activity within the first $24 \mathrm{~h}$ as well as Bti granules used as a positive control, as illustrated in Figure 2. Given that temephos and Bti are currently the most used larvicidal agents to fight mosquito larvae, with the challenge of larvae resistance to temephos and the high cost of Bti production on a large scale, natural products such as O. kilimandscharicum oil present alternative larvicide sources when properly formulated. Moreover, several phytochemicals, particularly from the Lamiaceae family, have been found to possess larvicidal activity against larvae of Ae. aegypti, An. gambiae, An. arabiensis, and Cx. quinquefasciatus, including Lippia alba, O. sanctum, O. gratissimum, and O. basilicum $[38,39,60,64]$. In addition, recently EO from Origanum vulgar has shown good larvicidal activity against $A$ e. aegypti at $20 \mathrm{ppm}$ before formulation into water emulsion $[63,64]$. The use of this plant's EO as larvicide has been limited due to the complication of immiscibility in water and the loss of activity due to high volatility [65]. However, phytochemical-combined formulations can improve activity and improve delivery for effective vector control [66]. As such, the present study lays the useful groundwork for the practical application of essential oil from $O$. kilimandscharicum as a mosquito larvicidal product. The bioactive formulation has the advantage of high solubility in aqueous media; it is also easily produced, ecofriendly, and affordable. However, given that the plant grows widely in different agro-ecological areas in tropical Africa, and for effective downstream applications, it will be helpful to compare the composition (epigenetic/chemotypes variations) and larvicidal effects of essential oil of the plants growing in different locations. In addition, it will also be helpful to evaluate essential oils from other plants with similar bioactivity for blending or ensuring sustainability. The plant world provides a rich untapped pool of phytochemicals that may offer alternatives to synthetic insecticides in mosquito control programs [64,67]. Moreover, for long-term efficacy and deployment, there is a need to evaluate the contribution of each of their components on the bioactivity of each blend and assess their resistance-mitigating effects [68]. In addition, the effects on the nontarget organism in the aquatic environment need to be determined in detail. 


\section{Conclusions}

The emulsified O. kilimandscharicum oil formulation exhibited significant larvicidal activity against $A n$. gambiae and $A n$. arabiensis larvae. Despite its direct toxicity to the larvae, its significant sublethal effects were an additional hallmark to demonstrate the further activity of this plant extract through morphological and physiological anomalies, making emulsified $O$. kilimandscharicum oil formulation a potential candidate to be used as a new plant-based insecticide to control disease vectors. Moreover, due to the fact that $O$. kilimandscharicum plant has high EO yields and can be easily and widely cultivated, it is a valuable alternative for the effective and eco-friendly control of disease vectors for both developing and developed communities.

Author Contributions: Conceptualization, J.B.O., C.M.M., B.F.H., A.H. and W.L.; Data curation, R.M.M.; Formal analysis, J.B.O.; Funding acquisition, J.B.O.; Investigation, C.M.M., B.F.H. and A.H.; Methodology, J.B.O., C.M.M., R.M.M., A.H. and W.L.; Project administration, C.M.M.; Supervision, W.L.; Visualization, B.F.H., A.H. and W.L.; Writing-original draft, J.B.O., R.M.M. and W.L.; Writingreview \& editing, J.B.O., R.M.M., B.F.H., A.H. and W.L. All authors have read and agreed to the published version of the manuscript.

Funding: This research was funded by the Biovision Foundation Switzerland (Grant number BV HH-07/2016-18). The article processing charge (APC) was funded by: Global Environment Facility, Project ID 4668. The funding bodies have no role in the design of the study, collection, analysis, and interpretation of data or in writing the manuscript. The views and opinions expressed in this publication are those of the authors and do not necessarily reflect those of ICIPE or the donors.

Institutional Review Board Statement: Not applicable.

Informed Consent Statement: Not applicable.

Data Availability Statement: All data generated or analyzed during this study are included in this manuscript.

Acknowledgments: To Lamberts Moreka for conducting the assays, Milkah Gitau, and Jenniffer Thiong'o for the provision of larval material from the insectary and conducting assays.

Conflicts of Interest: The authors declare no conflict of interest.

\section{References}

1. Rueda, L.M. Global diversity of mosquitoes (Insecta: Diptera: Culicidae) in freshwater. Hydrobiologia 2008, 595, 477-487. [CrossRef]

2. WHO. World Malaria Report; World Health Organization: Geneva, Switzerland, 2019.

3. Paixão, E.S.; Teixeira, M.G.; Rodrigues, L.C. Zika, chikungunya and dengue: The causes and threats of new and reemerging arboviral diseases. BMJ Glob. Health 2018, 3, e000530. [CrossRef]

4. Brown, A.W.A. Insecticide resistance in mosquitoes: A pragmatic review. J. Am. Mosq. Control Assoc. 1986, $2,123$.

5. Liu, H.; Xu, Q.; Zhang, L.; Liu, N. Chlorpyrifos Resistance in Mosquito Culex quinquefasciatus. J. Med. Entomol. 2005, 42, 815-820. [CrossRef]

6. Ghebreyesus, T.A. World Malaria Report 2005; World Health Organization: Geneva, Switzerland, 2005.

7. Couston, M. L'Assemblee mondiale de l'oms. In Proceedings of the Sixty-Eighth World Health Assembly, Geneva, Switzerland, 18-26 May 2015.

8. Lee, S.C.; Kim, J.H.; Lee, S.J. Floating of the lobes of mosquito (Aedes togoi) larva for respiration. Sci. Rep. 2017, 7, 43050. [CrossRef]

9. Pavel, R. Acute toxicity and synergistic and antagonistic effects of the aromatic compounds of some essential oils against Culex quinquefasciatus Say larvae. Parasitol. Res. 2015, 114, 3835-3853. [CrossRef]

10. Arnason, J.T.; Philogene, B.J.R.; Morand, P. ChemInform Abstract: Insecticides of Plant Origin (ACS Symposium Series No. 387). ChemInform 1990, 21. [CrossRef]

11. Hedlin, P.A.; Hollingworth, R.M.; Masler, E.P.; Miyamoto, J.; Thompson, D.G. Phytochemicals for Pests Control. J. Am. Chem. Soc. 1997, 658, 388.

12. Pavela, R.; Vrchotová, N. Insecticidal effect of furanocoumarins from fruits of Angelica archangelica L. against larvae Spodoptera littoralis Bois. Ind. Crops Prod. 2013, 43, 33-39. [CrossRef]

13. Pavel, R. Insecticidal properties of Pimpinella anisum essential oils against the Culex quinquefasciatus and the non-target organism Daphnia magna. J. Asia-Pac. Entomol. 2014, 17, 287-293. [CrossRef] 
14. Bouzid, M.; Colón-González, F.J.; Lung, T.; Lake, I.R.; Hunter, P.R. Climate change and the emergence of vector-borne diseases in Europe: Case study of dengue fever. BMC Public Health 2014, 14, 781. [CrossRef]

15. Kangethe, L.N.; Ahmed, H.; Omar, S.; Gathirwa, J.; Kirra, P.; Kaniaru, S.; Kamau, T.; Kimani, F.; Nganga, J.K.; Irungu, L. Synergistic Antiplasmodial Activity of Artemisia annua fractions against in vitro cultures of Plasmodium falciparum. Afr. J. Pharmacol. Ther. 2016, 5, 201-205.

16. Seyoum, A.; Killeen, G.F.; Kabiru, E.W.; Knols, B.G.J.; Hassan, A. Field efficacy of thermally expelled or live potted repellent plants against African malaria vectors in western Kenya. Trop. Med. Int. Heath. 2003, 8, 1005-1011. [CrossRef]

17. Santana-Méridas, O.; González-Coloma, A.; Sánchez-Vioque, R. Agricultural residues as a source of bioactive natural products. Phytochem. Rev. 2012, 11, 447-466. [CrossRef]

18. Walker, K.; Lynch, M. Contributions of Anopheles larval control to malaria suppression in tropical Africa: Review of achievements and potential. Med Vet.-Èntomol. 2007, 21, 2-21. [CrossRef]

19. Fillinger, U.; Lindsay, S.W. Larval source management for malaria control in Africa: Myths and reality. Malar. J. 2011, 10, 353. [CrossRef]

20. Junqueira, J.; Mendes, J. Susceptibility of Aedes aegypti (L) to the insect growth regulators diflubenzuron and methoprene in Uberlândia, State of Minas Gerais. Rev. Soc. Bras. Med. Trop. 2007, 40, 612-616. [CrossRef]

21. Marcombe, S.; Darriet, F.; Agnew, P.; Etienne, M.; Yp-Tcha, M.M.; Yébakima, A.; Corbel, V. Field efficacy of new larvicide products for control of multi-resistant Aedes aegypti populations in Martinique (French West Indies). Am. J. Trop. Med. Hyg. 2011, 84, 118-126. [CrossRef]

22. World Health Organization. Whopes-recommended compounds and formulations for control of mosquito larvae. PLoS Negl. Trop. Dis. 2016, 10, e0005235.

23. Khan, G.Z.; Khan, I.; Khan, I.; Ali, A.; Salman, M.; Ullah, K. Evaluation of different formulations of IGRs against Aedes albopictus and Culex quinquefasciatus (Diptera: Culicidae). Asian Pac. J. Trop. Biomed. 2016, 6, 485-491. [CrossRef]

24. Imbahale, S.S.; Mukabana, W.R. Efficacy of neem chippings for mosquito larval control under field conditions. BMC Ecol. 2015, 15, 8. [CrossRef]

25. Sukumar, K.; Perich, M.J.; Booba, L.R. Botanical derivatives in mosquito control: A review. J. Am. Mosq. Control Assoc. 1991, 7, 210-237.

26. Said-Al, H.A.H.; Said-Al, A.H.L.; Hussein, A.H.; Hikal, W.M.; Tkachenko, K.G. Essential Oils with Potential as Insecticidal Agents: A Review. Int. J. Environ. Plan. Manag. 2017, 3, 23-33.

27. Gajger, I.T.; Dar, S.A. Plant Allelochemicals as Sources of Insecticides. Insects 2021, 12, 189. [CrossRef]

28. Pavel, R. Essential oils for the development of eco-friendly mosquito larvicides: A review. Ind. Crops Prod. 2015, 76, 174-187. [CrossRef]

29. Isman, M.B. Plant essential oils for pest and disease management. Crop Prot. 2000, 19, 603-608. [CrossRef]

30. Stahl-Biskup, E.; Sáez, F. Thyme: The Genus Thymus; CRC Press: Hamburg, Germany, 2003; pp. 1-333.

31. Miresmailli, S.; Isman, M.B. Botanical insecticides inspired by plant-herbivore chemical interactions. Trends Plant Sci. 2014, 19, 29-35. [CrossRef]

32. Ghosh, A.; Chowdhury, N.; Chandra, G. Plant extracts as potential mosquito larvicides. Indian J. Med. Res. 2012, 135, 581-598.

33. Soni, N.; Gill, D.; Sagar, B.S.; Raheja, S.; Agrawal, S. Ocimum kilimandscharicum: A Systematic Review. J. Drug Deliv. Ther. 2012, 2, 45-52. [CrossRef]

34. Njoroge, G.N.; Bussmann, R.W.; Gemmill, B.; Newton, L.E.; Ngumi, V.W. Utilisation of weed species as sources of traditional medicines in central Kenya. Lyonia 2004, 7, 71-87.

35. Kashyap, C.P.; Ranjeet, K.; Vikrant, A.; Vipin, K. Therapeutic Potency of Ocimum kilimandscharicumguerke-A Review. Glob. J. Pharmacol. 2011, 5, 191-200.

36. Sarin, R.V.; Narwal, S.; Bafna, P.A. Anti-diarrhoeal activity of aqueous extract of Ocimum kilimandscharicum. J. Ethnopharmacol. 2013, 148, 223-228. [CrossRef] [PubMed]

37. Mukungu, N.; Abuga, K.; Okalebo, F.; Ingwela, R.; Mwangi, J. Medicinal plants used for management of malaria among the Luhya community of Kakamega East sub-County, Kenya. J. Ethnopharmacol. 2016, 194, 98-107. [CrossRef] [PubMed]

38. Singh, D. Advances in Plant Biopesticides; Springer: New Delhi, India, 2014; pp. 1-401. [CrossRef]

39. Ostertag, F.; Weiss, J.; McClements, D.J. Low-energy formation of edible nanoemulsions: Factors influencing droplet size produced by emulsion phase inversion. J. Colloid Interface Sci. 2012, 388, 95-102. [CrossRef] [PubMed]

40. WHO. Guidelines for Laboratory and Field Testing of Mosquito Larvicides; World Health Organization: Geneva, Switzerland, 2005.

41. Abbott, W.S. A method of computing the effectiveness of an insecticide. J. Am. Mosq. Control Assoc. 1925, 18, 265-267. [CrossRef]

42. WHO. Larval Source Management-A Supplementary Measure for Malaria Vector Control: An Operational Manual; World Health Organization: Geneva, Switzerland, 2013; p. 128.

43. Singh, K.; Singh, D.K. Toxicity to the snail Limnaea acuminata of plant-derived molluscicides in combination with synergists. Pest Manag. Sci. 2000, 56, 889-898. [CrossRef]

44. Wei, X.; Koo, I.; Kim, S.; Zhang, X. Compound identification in GC-MS by simultaneously evaluating the mass spectrum and retention index. Analyst 2014, 139, 2507-2514. [CrossRef]

45. Wassmer, C.S.; Grau, G.E.R. Severe malaria: What's new on the pathogenesis front? Int. J. Parasitol. 2017, 47, 145-152. [CrossRef] 
46. Ohia, C.M.D.; Ana, G.R.E.E. Bio-insecticides: The one-health response to mosquitoborne diseases of public health importance. J. Biol. Agric. Healthc. 2015, 5, 22-26.

47. Bekele, J.; Hassanali, A. Blend effects in the toxicity of the essential oil constituents of Ocimum kilimandscharicum and Ocimum kenyense (Labiateae) on two post-harvest insect pests. Phytochemistry 2001, 57, 385-391. [CrossRef]

48. Dua, V.K.; Pandey, A.C.; Raghavendra, K.; Gupta, A.; Sharma, T.; Dash, A.P. Larvicidal activity of neem oil (Azadirachta indica) formulation against mosquitoes. Malar. J. 2009, 8, 124-126. [CrossRef] [PubMed]

49. Lawrence, A.K.; Olorunfemi, O.S. Investigation of changes in the levels of some tissue biochemicals in Culex quinquefasciatus (Diptera: Culicidae) exposed to sublethal toxicity of Cypermethrin. Sci. Afr. 2019, 4, e00109. [CrossRef]

50. Balandrin, M.F.; Klocke, J.A. Medicinal, Aromatic, and Industrial Materials from Plants. In Medicinal and Aromatic Plants I. Biotechnology in Agriculture and Forestry; Bajaj, Y.P.S., Ed.; Springer: Berlin/Heidelberg, Germany, 1988; Volume 4. [CrossRef]

51. Aygun, D.; Doganay, Z.; Altintop, L.; Guven, H.; Onar, M.; Deniz, T.; Sunter, T. Serum acetylcholinesterase and prognosis of acute organophosphate poisoning. J. Toxicol.—Clin. Toxicol. 2002, 40, 903-910. [CrossRef]

52. Enan, E. Insecticidal activity of essential oils: Octopaminergic sites of action. Comp. Biochem. Physiol.-Part C Toxicol. Pharmacol. 2001, 130, 325-337. [CrossRef]

53. Obeng-Ofori, D.; Reichmuth, C.H.; Bekele, A.J.; Hassanali, A. Toxicity and protectant potential of camphor, a major component of essential oil of Ocimum kilimandscharicum, against four stored product beetles. Int. J. Pest Manag. 1998, 44, 203-209. [CrossRef]

54. Fournier, D.; Mutero, A. Modification of acetylcholinesterase as a mechanism of resistance to insecticides. Comp. Biochem. Physiol.-Part C Toxicol. Pharmacol. 1994, 108, 19-31. [CrossRef]

55. Kostyukovsky, M.; Rafaeli, A.; Gileadi, C.; Demchenko, N.; Shaaya, E. Activation of octopaminergic receptors by essential oil constituents isolated from aromatic plants: Possible mode of action against insect pests. Pest Manag. Sci. 2002, 58, 1101-1106. [CrossRef]

56. Miyazawa, M.; Watanabe, H.; Kameoka, H. Inhibition of acetylcholinesterase activity by monoterpenoids with a methane skeleton. J. Agric. Food Chem. 1997, 45, 677-679. [CrossRef]

57. Mordue, A.J.; Blackwell, A. Azadirachtin: An update. J. Insect Physiol. 1993, 39, 903-924. [CrossRef]

58. Grundy, D.L.; Still, C.C. Inhibition of acetylcholinesterases by pulegone1,2-epoxide. Pestic. Biochem. Physiol. 1985, 23, 383-388. [CrossRef]

59. Schmutterer, H. Properties and potential of natural pesticides from the neem tree, Azadirachta indica. Annu. Rev. Entomol. 1990, 35, 271-297. [CrossRef] [PubMed]

60. Coats, J.R.; Karr, L.L.; Drewes, C.D. Toxicity and Neurotoxic Effects of Monoterpenoids. In Insects and Earthworms; ACS Symposium Series; Department of Entomology and Department of Zoology; Iowa State University: Ames, IA, USA, 1991; pp. 305-316.

61. Ryan, M.F.; Byrne, O. Plant-insect coevolution and inhibition of acetylcholinesterase. J. Chem. Ecol. 1988, 14, 1965-1975. [CrossRef] [PubMed]

62. Rajamma, A.; Dubey, S.; Sateesha, S.; Tiwari, S.; Ghosh, S. Comparative larvicidal activity of different species of Ocimum against Culex quinquefasciatus. Nat. Prod. Res. 2011, 25, 1916-1922. [CrossRef] [PubMed]

63. Singh, P.; Jayaramaiah, R.H.; Sarate, P.; Thulasiram, H.V.; Kulkarni, M.J.; Giri, A.P. Insecticidal potential of defense metabolites from Ocimum kilimandscharicum against Helicoverpa armigera. PLoS ONE 2014, 9, e104377. [CrossRef]

64. Chaves, R.D.S.B.; Martins, R.L.; Rodrigues, A.B.L.; Érica, D.M.R.; Farias, A.L.F.; Brandão, L.B.; Santos, L.L.; Galardo, A.K.R.; de Almeida, S.S.M.D.S. Evaluation of larvicidal potential against larvae of Aedes aegypti (Linnaeus, 1762) and of the antimicrobial activity of essential oil obtained from the leaves of Origanum majorana L. PLoS ONE 2020, 15, e0235740. [CrossRef] [PubMed]

65. Ferreira, T.P.; Haddi, K.; Corrêa, R.F.T.; Zapata, V.L.; Piau, T.B.; Souza, L.F.; Santos, S.M.G.; Oliveira, E.E.; Jumbo, L.O.; Ribeiro, B.M.; et al. Prolonged mosquitocidal activity of Siparuna guianensis essential oil encapsulated in chitosan nanoparticles. PLoS Negl. Trop. Dis. 2019, 13, e0007624. [CrossRef]

66. Asawalam, E.F.; Emosairue, S.O.; Hassanali, A. Contribution of different constituents to the toxicity of the essential oil constituents of Vernonia amygdalina (Compositae) and Xylopia aetiopica (Annonaceae) on maize weevil, Sitophilus zeamais Motschulsky (Coleoptera: Curculionidae). Afr. J. Biotechnol. 2008, 7, 2957-2962. [CrossRef]

67. Dhifi, W.; Bellili, S.; Jazi, S.; Bahloul, N.; Mnif, W. Essential Oils' Chemical Characterization and Investigation of Some Biological Activities: A Critical Review. Medicines 2016, 3, 25. [CrossRef]

68. Kishore, N.; Mishra, B.B.; Tiwari, V.K.; Tripathi, V. A Review on Natural Products with Mosquitocidal Potentials. In Opportunity, Challenge, and Scope of Natural Products in Medicinal Chemistry; ScienceOpen, Inc.: Burlington, MA, USA, 2011. 